\title{
The relationship between kinesiophobia and disability, pain and anxiety in patients with chronic shoulder pain: A case control study
}

\author{
Burhan Fatih Kocyigit $^{1}$, Ahmet Akyol ${ }^{2}$
}

${ }^{1}$ Department of Physical Medicine and Rehabilitation, School of Medicine, Kahramanmaras Sutcu Imam University, Kahramanmaras, Turkey

${ }^{2}$ Department of Physical Medicine and Rehabilitation, Hasan Kalyoncu University, Kalyon Medical Center, Gaziantep, Turkey

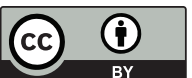

This work is licensed under a Creative Commons Attribution 4.0 International License

Received: 2020-04-20

Accepted: 2020-05-12

UDC: 618.1

J Clin Med Kaz 2020; 3(57):29-34

Corresponding Author: Burhan Fatih Kocyigit, Department of Physical Medicine and Rehabilitation, Kahramanmaras Sutcu Imam University School of Medicine, Kahramanmaras, Turkey.

E-mail: bfk2701@hotmail.com

\section{Abstract}

Objective: Physical and psychological factors affect disability in patients with chronic shoulder pain. Kinesiophobia which is described as fear of movement may induce disability. Therefore, we aimed to compare kinesiophobia levels between patients with chronic shoulder pain and healthy volunteers and to determine the correlations between kinesiophobia and disability, pain and anxiety.

Material and methods: This is a case-control study. 54 patients with shoulder pain and 56 healthy volunteers similar to case group in terms of age, sex and body mass index were enrolled in this research. Patients were evaluated with visual analogue scale, active range of motion measurements, Tampa Scale for Kinesiophobia, Shoulder Pain and Disability Index and Beck Anxiety Inventory.

Results: Tampa Scale for Kinesiophobia, Shoulder Pain and Disability Index-pain, Shoulder Pain and Disability Index-disability and Beck Anxiety Inventory scores were significantly higher in the patient group $(p<0.05)$. Tampa Scale for Kinesiophobia scores were significantly and positively correlated with visual analogue scale, Shoulder Pain and Disability Index-pain, Shoulder Pain and Disability Index-disability and Beck Anxiety Inventory scores ( $\mathrm{r}=0.334$, $\mathrm{p}=0.014 ; \mathrm{r}=0.585, \mathrm{p}<0.001 ; \mathrm{r}=0.540, \mathrm{p}<0.001$ and $\mathrm{r}=0.419, \mathrm{p}<0.001)$. Tampa Scale for Kinesiophobia scores were significantly and negatively correlated with range of motion-flexion, range of motion-abduction and range of motionextension $(\mathrm{r}=-0.438, \mathrm{p}=0.001 ; \mathrm{r}=-0.373, \mathrm{p}=0.005$ and $\mathrm{r}=-0.278, \mathrm{p}=0.042)$. No significant correlation was detected between Tampa Scale for Kinesiophobia scores and symptom duration $(\mathrm{p}>0.05)$.

Conclusion: Kinesiophobia is associated with disability, pain and anxiety in patients with chronic shoulder pain. Therefore, factors associated with kinesiophobia should be clearly identified and strategies should be created to improve kinesiophobia levels.

Key words: kinesiophobia, shoulder pain, disability

\section{СОЗЫЛМАЛЫ ИЫҚ АУРУЫ БАР НАУҚАСТАРДАҒЫ КИНЕЗОФОБИЯ МЕН ШЕКТЕУЛІ ҚОЗҒАЛЫС, АУЫРСЫНУ} ЖӘНЕ АЛАНДАУШЫЛЫҚ АРАСЫНДАҒЫ БАЙЛАНЫС: ЖАҒДАЙДЫ БАҚЫЛАУ БОЙЫНША ЗЕРТТЕУ

\section{Б.Ф. Кочигит ${ }^{1}$, А. Акйол ${ }^{2}$}

${ }^{1}$ Физиотерапия және реабилитация кафедрасы, Медицина мектебі, Сутчу Имам Университеті, Кахраманмараш, Түркия

${ }^{2}$ Физиотерапия және реабилитация кафедрасы, Хасан Калёнджу университеті, Калион медициналық орталығы, Газиантеп, Түркия

\section{ТҰЖЫРЫМдАМА}

Мақсаты: Созылмалы иық ауруы бар науқастарда фризикалық және психологиялық факторлар қозғалыстың шектелуіне әсер етеді. Қозғалыс қорқынышы ретінде сипатталған кинезиофробия қозғалыстың шектелуіне әкелуі мүмкін. Сондықтан бұл зерттеудің мақсаты созылмалы иық ауруы бар пациенттер мен сау еріктілер арасындағы кинезиофобия деңгейлерін салыстыру және кинезофобия мен қозғалыс шектеуі, ауырсыну мен мазасыздық арасындағы байланысты анықтау болды.

Материалы және әдістері: Бұл зерттеудің әдісі - жағдайды бақылау. Зерттеуге иық ауруы бар 54 пациент және жасына, жынысына және дене салмағының индексі бойынша науқастар тобына ұқсас 56 сау еріктілер кірді. Пациенттерге визуалды аналогтық шкала, белсенді қозғалыстар көлемін өлшеу, Тампа кинезиофобия шкаласы, иық ауыруы салдарынан мүгедектік индексі және Бектің мазасыздық сауалнамасы қолданылды. 
Нәтижелері: Тампа кинезиофобиясының шкаласы, иық ауруы салдарынан мүгедектік индексі және Бек мазасыздық сауалнамасы пациенттер тобында едәуір жоғары болды ( $<0.05)$. Тампа кинезиофобиясы шкаласының мәні көрнекі аналогтық шкаланың, иықтың ауыруы мен мүгедектіктің индексі және Бек мазасыздық сауалнамасының мәндерімен едәуір және оң корреляцияланған $(r=0.334, p=0.014 ; r=$ 0.585, $p<0.001 ; r=0.540, p<) 0,001$ және $r=0.419, p<0.001)$.

Тампа кинезиофобиясы шкаласының мәні қозғалыс-иілу көлемінің, қозғалу-өсу көлемінің және қозғалыс-кеңейту көлемінің мәндерімен едәуір және теріс байланысты ( $r=-0.438, p=0.001 ; r=-0.373, p=0.005$ және $r=-0.278, p=0.042)$. Тампа кинезиофобиясы шкаласы мен белгілердің ұзақтығы арасында айтарлықтай байланыс жоқ (р>0.05).

Қорытындысы: Кинезиофобия созылмалы иық ауруы бар науқастарда шектеулі қозғалыс, ауырсыну және мазасыздықпен байланысты. Сондықтан, кинезиофобиямен байланысты факторлар нақты анықталып, кинезиофобияның деңгейін жақсартатын стратегияларды жасау керек.

Негізгі сөздер: кинезиофобия, иықтағы ауру, қозғалыс шектеулігі

\section{ВЗАИМОСВЯЗЬ МЕЖДУ КИНЕЗОФОБИЕЙ И ОГРАНИЧЕНИЕМ ДВИЖЕНИЙ, БОЛЬЮ И ТРЕВОГОЙ У ПАЦИЕНТОВ С ХРОНИЧЕСКОЙ БОЛЬЮ В ПЛЕЧЕ: ИССЛЕДОВАНИЕ СЛУЧАЙ-КОНТРОЛЬ}

\section{Б.Ф. Кочигит ${ }^{1}$, А. Акйол ${ }^{2}$}

${ }^{1}$ Кафедра физиотерапии и реабилитации, Школа медицины, Университет Сутчу Имам, Кахраманмараш, Турция

${ }^{2}$ Кафедра физиотерапии и реабилитации, Университет Хасана Калёнджу, Медицинский центр Калион, Газиантеп, Турция

\section{PEЗЮME}

Цель: Физические и психологические факторы влияют на ограничение движений у пациентов с хронической болью в плече. Кинезиофобия, которая описывается как страх выполнения движения, может вызвать ограничение движений. Поэтому целью данного исследования стало сравнение уровней кинезиофобии между пациентами с хронической болью в плече и здоровыми добровольцами и определение корреляции между кинезофобией и ограничениес движений, болью и тревогой.

Материал и методы: Метод данного исследования - случай-контроль. В исследование включены 54 пациента с болью в плече и 56 здоровых добровольцев, аналогичных группе пациентов по возрасту, полу и индексу массы тела. Пациентов оценивали с помощью визуальной аналоговой шкалы, измерений объема активных движений, шкалы кинезиофобии Тампа, индекса ограничения жизнедеятельности из-за боли в плече и опросника тревожности Бека.

Результаты: Значения шкалы кинезиофобии Тампа, индекса ограничения жизнедеятельности из-за боли в плече и опросника тревожности Бека были значительно выше в группе пациентов ( $<0.05)$. Значения шкалы кинезиофобии Тампа значительно и положительно коррелировали со значениями визуальной аналоговой шкалы, индекса ограничения жизнедеятельности из-за боли в плече и опросника тревожности Бека ( $r=0.334, p=0.014 ; r=0.585, p<0.001 ; r=0.540, p<0.001$ и $r=0.419, p<0.001)$. Значения шкалы кинезиофобии Тампа значительно и отрицательно коррелировали со значениями объема движения-сгибания, объема движения-разведения и объема движения-разгибания $(r=-0.438, p=0.001 ; r=-0.373, p=0.005$ и $r=-0.278, p=0.042)$. Существенной корреляции между значениями шкалы кинезиофобии Тампа и продолжительностью симптомов не было обнаружено ( $p>0.05)$.

Заключение: Кинезиофобия связана с ограничением движений, болью и беспокойством у пациентов с хронической болью в плече. Следовательно, фракторы, связанные с кинезиофобией, должны быть четко определены, и должны быть разработаны стратегии для улучшения уровней кинезиофобии.

Ключевые слова: кинезиофобия, боль в плече, ограничение движений

\section{Introduction}

Shoulder pain is one of the most common musculoskeletal problems in the population [1]. The lifetime prevalence of shoulder pain may rise up to $67 \%$ [2]. Shoulder pain does not ameliorate in half of all patients in the first six months. Additionally, $40 \%$ of patients still perceive pain after 12 months [3]. High recurrence rates and chronicity are the main problems of patients with shoulder disorders. Pain in the shoulder region, joint stiffness, and decrement in range of motion (ROM) are the major symptoms and signs of patients, which affect daily life activities, quality of life, and working performance [4, 5].

Factors such as age, sex, and psychological condition influence treatment responses and disability in musculoskeletal disorders [6]. Kinesiophobia, which is described as fear of movement or fear of re-injury, may elucidate disability and chronicity in patients with shoulder problems [7]. The fear avoidance model (FAM) has been recommended to explain how psychological factors such as kinesiophobia, affect chronicity and disability in patients with musculoskeletal problems [8]. FAM defines two paths for patients. In the first path, pain is not interpreted as threatening. Despite pain, patients continue their daily life activities, which induces recovery. This is defined as the adaptive pathway. In the second path, patients interpret pain as a threat, which triggers pain associated fear and avoidance behavior. This is defined as the maladaptive pathway, which causes chronicity, higher levels of perceived pain, lower levels of quality of life, hypervigilance, and disability [9]. FAM has been mainly investigated in patients with chronic low back pain [10]. Fear avoidance beliefs occur in early stages of the disease and influence the progression from acute to chronic low back pain [11]. Additionally, kinesiophobia has been found to be associated with disability in patients with knee osteoarthritis, neck pain, work related and non-work related musculoskeletal pain [12-14].

We assume that kinesiophobia is linked with disability in patients with chronic shoulder pain. Therefore, we aimed to compare kinesiophobia levels between patients with chronic shoulder pain and healthy volunteers and to investigate the correlations between kinesiophobia and disability, pain, ROM, and anxiety in patients with chronic shoulder pain.

\section{Material and methods Study design and participants}

This is a case-control study. Fifty-four patients who presented to our physical medicine and rehabilitation polyclinic with symptoms of shoulder pain between November 2017 and January 2018, and 56 healthy volunteers were enrolled in the study. Patients included in the study had diagnoses such as subacromial impingement syndrome, tendinitis, rotator cuff tear, biceps tendon lesion, glenohumeral joint osteoarthritis, and acromioclavicular joint osteoarthritis. Radiological evaluations were performed to make a diagnosis when necessary.

The inclusion criteria for patients in the study were, being aged of 18 years or above, having pain in the shoulder region, and having symptoms for at least 3 months. We did not determine a cut-off value for pain and included all patients regardless of pain 
level. Additionally, we did not set an upper age limit.

Patients who had previous shoulder surgery, trauma, fracture, dislocation, tumor, neurologic deficits on the affected side, frozen shoulder, excessive cervical radiculopathy, inflammatory joint disease, diabetes mellitus, and bilateral symptoms were excluded from the study. Additionally, patients who had received physical therapy and rehabilitation programs in the past six months and who received shoulder injections were also excluded.

\section{Data sources and measurement}

Assessment including age, sex, BMI, and symptom duration were recorded. Perceived pain intensity was evaluated using a visual analogue scale (VAS). Severity of pain was marked on the $10 \mathrm{~cm}$ long scale ( 0 points indicate no pain; 10 points indicate the most severe pain).

The most commonly used ROM measurement technique is goniometry [15]. All patients uncovered their affected arm to facilitate the shoulder ROMs and to expose bone reference points. Active shoulder joint flexion, abduction and extension ROMs were evaluated by the same physician using a standard goniometer. Active shoulder joint flexion and abduction were measured in the sitting position. Active shoulder joint extension was measured in the prone position [16]. Goniometric shoulder joint ROM measurement is a reliable method [17].

The kinesiophobia level was assessed using the Turkish version of the Tampa Scale for Kinesiophobia (TSK), which includes 17 questions [18]. The minimum score of each question is 1 point (indicates complete disagreement), the maximum score of each question is 4 points (indicates complete agreement). The maximum score of the scale is 68 points. Higher scores indicate higher levels of kinesiophobia.

The shoulder Pain and Disability Index (SPADI) consists of two subscales. The pain subscale includes 5 items, and the

\begin{tabular}{|c|c|c|c|}
\hline Table 1 & \multicolumn{3}{|c|}{$\begin{array}{l}\text { Comparison of Age, Sex and BMI between } \\
\text { Patient and Control Groups }\end{array}$} \\
\hline & Patient Group & Control Group & $\mathrm{p}$ \\
\hline Age*(year) & $50(23-75)$ & $45(19-72)$ & $0.139 \mathrm{a}$ \\
\hline $\begin{array}{l}\text { Female (n) } \\
\text { Male (n) }\end{array}$ & $\begin{array}{l}35 \\
19\end{array}$ & $\begin{array}{l}39 \\
17\end{array}$ & $0.590 \mathrm{~b}$ \\
\hline BMI* & $27.62(18.51-46.87)$ & $26.5(19.85-36.88)$ & $0.130 \mathrm{a}$ \\
\hline
\end{tabular}

*Data was shown as median (minimum-maximum), a p value was calculated with Mann-Whitney U test, b p value was calculated with ChiSquare test, n: number, BMI: Body mass index.

Table 3 Correlations between Clinical Parameters and TSK Scores

\begin{tabular}{|l|l|l|}
\hline & rho & $\mathrm{p}$ \\
\hline Symptom duration (month) & 0.197 & 0.154 \\
\hline VAS & 0.334 & 0.014 \\
\hline ROM-flexion & -0.438 & 0.001 \\
\hline ROM-abduction & -0.373 & 0.005 \\
\hline ROM-extension & -0.278 & 0.042 \\
\hline SPADI-pain & 0.585 & $<0.001$ \\
\hline SPADI-disability & 0.540 & $<0.001$ \\
\hline BAI & 0.419 & $<0.001$ \\
\hline
\end{tabular}

disability subscale includes 8 items. Each item is scored between 0 points (minimum) and 10 points (maximum) [19]. Higher scores show higher levels of pain and disability.

The anxiety level of the participants was evaluated using the Beck Anxiety Inventory (BAI). The BAI consists of 21 items. Each item has four possible answer choices: not at all ( 0 points $)$, mild ( 1 point), moderate ( 2 points), and severe ( 3 points). The total score of the scale can range between 0 and 63 points. Higher scores indicate higher levels of anxiety [20].

\section{Ethics statement}

This research was approved by the local ethics committee. Written informed consent was obtained each patient and healthy volunteer before participating in the study.

\section{Statistical Analysis}

Statistical analyses of data were utilized using the Statistical Package for Social Sciences (SPSS) for Windows version 20.0 package programme (SPSS Inc., Chicago, IL, USA). Mean \pm standard deviation, median (minimum-maximum), number and percentage were used to express the data. According to the results of Shapiro-Wilk test, it was determined whether the data show normal distribution or not. Two group comparisons for continuous variables were performed using the independent sample $t$ test or Mann-Whitney U test depending on the ShapiroWilk test results. For categorical variables, the Chi-Square test was performed to compare the groups. Correlations between TSK scores and clinical parameters were assessed using the Spearman rho test. Significance value was considered as 0.05 .

\section{Results}

A total of 54 ( 35 females, 19 males) patients and 56 healthy volunteers (39 females, 17 males) were enrolled in the study. No significant differences were found between the patient and control groups in terms of age, sex, and BMI ( $>>0.05)$ (Table 1).

Table 2

Comparison of kinesiophobia, pain, disability and anxiety scores between patient and control groups

\begin{tabular}{|l|l|l|l|}
\hline & Patient Group & Control Group & $\mathrm{p}$ \\
\hline TSK $^{* *}$ & $41.98 \pm 8.42$ & $36.10 \pm 10.36$ & $0.002 \mathrm{~b}$ \\
\hline SPADI-pain* & $38(21-49)$ & $26.50(12-41)$ & $<0.001 \mathrm{a}$ \\
\hline SPADI-disability* & $52(15-80)$ & $40(16-59)$ & $<0.001 \mathrm{a}$ \\
\hline BAI $^{*}$ & $14(2-55)$ & $10.50(2-32)$ & $0.013 \mathrm{a}$ \\
\hline
\end{tabular}

*Data was shown as median (minimum-maximum), **Data was shown as mean \pm standard deviation, TSK: Tampa Scale for Kinesiophobia, SPADIpain: Shoulder Pain and Disability Index pain subscale, SPADI-disability: Shoulder Pain and Disability Index disability subscale, BAI: Beck Anxiety Inventory, a p value was calculated with Mann-Whitney $U$ test, b p value was calculated with independent sample t test.

TSK, SPADI-pain, SPADI-disability, and BAI scores were significantly higher in the patient group as compared with the control group $(\mathrm{p}<0.05)$ (Table 2$)$.

TSK scores were significantly and positively correlated with VAS, SPADI-pain, SPADI-disability, and BAI scores $(\mathrm{r}=0.334, \mathrm{p}=0.014 ; \mathrm{r}=0.585, \mathrm{p}<0.001 ; \mathrm{r}=0.540, \mathrm{p}<0.001$ and $\mathrm{r}=0.419, \mathrm{p}<0.001)$. Additionally, TSK scores were significantly and negatively correlated with ROM-flexion, ROM-abduction, and ROM-extension $(r=-0.438, p=0.001 ; r=-0.373, p=0.005$ and $r=-0.278, p=0.042)$. No significant correlation was detected between TSK scores and symptom duration $(\mathrm{p}>0.05)$ (Table 3$)$. 


\section{Discussion}

Kinesiophobia, pain, disability, and anxiety were significantly higher in the patient group. Kinesiophobia was significantly and positively correlated with pain, disability, and anxiety. Additionally, kinesiophobia was significantly and negatively correlated with active shoulder ROMs. No significant correlation was found between kinesiophobia and symptom duration. We hypothesized that psychological, social, cognitive, and physical variables might contribute to disability in patients with musculoskeletal disorders. FAM, which was investigated in chronic low back pain, confirms our hypothesis. FAM has been suggested to explain which psychological factors such as fear of pain, fear of movement, fear of re-injury and pain catastrophizing contribute to the progression of chronicity and disability [8]. Vlaeyen et al. [9]. evaluated FAM in patients with low back pain, and fear of pain was found to be a predictive factor for progression of chronic low back pain following an acute onset. In this model, some patients enter the vicious cycle of pain related fear, fear of movement, fear of re-injury, hypervigilance, and avoidance behavior. This cycle is associated with higher perceived pain, chronicity, hypersensitivity, and disability.

FAM was mostly confirmed in patients with chronic low back pain [21]. The number of studies evaluating the effects of kinesiophobia in patients with chronic shoulder pain is limited. Lentz et al. [7]. examined 142 patients with unilateral and nonoperative shoulder pain and evaluated fear of pain using the TSK-11. Symptom duration, pain level, shoulder flexion ROM, and fear of pain were found to be associated with shoulder function. Feleus et al. [22]. evaluated patients with non-traumatic arm, neck, and shoulder symptoms and found positive relations between kinesiophobia and catastrophizing, and disability. Additionally, patients with shoulder symptoms had higher kinesiophobia scores in their study. The shoulder joint has a larger and more central structure than hand, wrist and elbow joints. It provides stability and mobility of the upper extremity in different postures and movements [23]. These characteristics of the shoulder joint may explain the results. Kinesiophobia levels may influence pain, disability, and functionality after surgery [24]. It was determined that kinesiophobia is a risk factor for knee ROM limitation after arthroplasty [25]. The above mentioned research confirms our results, which show associations between kinesiophobia and pain, and disability. We assessed disability with both active shoulder ROMs and a self-reported scale. A relationship between kinesiophobia and disability was detected with both methods. No significant correlation was detected between symptom duration and kinesiophobia in our study. Patients with chronic symptoms were included in the study; however, patients with acute and subacute symptoms were not evaluated. This study design may have affected the correlation between kinesophobia and symptom duration. Bot et al. [26]. evaluated 443 patients with shoulder and neck pain in their study. High levels of worrying were found to be associated with low recovery rates during 12 months of follow-up in their study. Worrying leads to a preoccupation with symptoms, which may aggravate perceived pain and disability. In our study, we determined a positive correlation between kinesiophobia and anxiety. Higher levels of worrying and anxiety may influence kinesiophobia and disability in patients with chronic shoulder pain.

In the ALTO study, the effects of kinesiophobia in musculoskeletal pain management particularly when treated by physical therapy and rehabilitation were evaluated [27].
The ALTO study indicated that kinesiophobia was related with higher pain intensity, older age, and less physical activity in patients with musculoskeletal pain and also demonstrated that kinesiophobia decreased satisfaction of physical therapy and participation of patients in physical therapy programmes. Damsgard et al. [28]. reported that kinesiophobia was a pivotal factor for greater pain during both daily life activities and exercise. Exercise is one of the crucial treatment methods in musculoskeletal system disorders particularly in shoulder pathologies [29]. However, exercise can increase the level of pain in some patients [30]. Studies have demonstrated the analgesic effects of exercise. However, exercise shows analgesic affects slowly and increases pain levels in the early phase [31]. This condition can increase kinesiophobia in some patients. It was demonstrated that education programs focused on kinesiophobia and avoidance behaviors decreased the fear of movement [32]. Cognitive-behavioral therapy, particularly exposure therapy, has been found to be beneficial in decreasing pain catastrophizing [33]. Virtual reality programs including mirror therapy, motor imagery, virtual walking and games were found to be useful for reducing pain and kinesiophobia [34]. Strategies to cope with pain and the importance of continuing daily life activities should be explained. Kinesiophobia is a major factor that decreases participation of patients in exercise and physical therapy programs. Therefore, factors associated with kinesiophobia should be clearly identified and strategies should be created to improve kinesiophobia related factors such as anxiety, depression, and pain. It should be aimed to increase compliance with exercise programs (home-based and/or hospital-based).

This study has some limitations. The sample size was small. We did not evaluate patients with acute or subacute pain. For this reason, we could not compare patients with acute pain and patients with chronic pain. We did not evaluate other physiologic factors such as depression, and, pain catastrophizing. Besides VAS, no other scale was used for pain assessment. This study was not planned with a longitudinal follow up design; therefore, we were not able to assess how kinesiophobia levels influenced the treatment success.

\section{Conclusion}

We believe that kinesiophobia is one of the key factors that can influence treatment responses in patients with chronic shoulder pain. Therefore, scales evaluating kinesiophobia may provide beneficial information that can be used to optimize physical therapy and exercise programs. Suggesting general exercise programs to patients should be avoided. Special physical therapy and exercise programs should be prepared for each patient, taking into account the kinesiophobia level, depression, anxiety, and pain. Physicians should consider the associations between kinesiophobia and disability when preparing, performing, and monitoring daily therapeutic exercise programs. Besides traditional rehabilitation practices, multidisciplinary rehabilitation programs consisting of education, cognitivebehavioral therapy, biofeedback, and virtual training methods should be applied to patients. Future longitudinal follow-up studies should center on developing strategies to cope with kinesiophobia in chronic musculoskeletal disorders.

Disclosures: There is no conflict of interest for all authors. 


\section{References}

1. Ostör AJK, Richards CA, Prevost AT, Speed CA, Hazleman BL. Diagnosis and relation to general health of shoulder disorders presenting to primary care. Rheumatology (Oxford). 2005; 44(6):800-805. https://doi.org/10.1093/rheumatology/keh598

2. Luime JJ, Koes BW, Hendriksen IJM, Burdorf A, Verhagen AP, Miedema HS, et al. Prevalence and incidence of shoulder pain in the general population; a systematic review. Scand J Rheumatol. 2004; 3(2):73-81. https://doi.org/10.1080/03009740310004667

3. Van Der Windt DAWM, Koes BW, Boeke AJP, Devillé W, De Jong BA, Bouter LM. Shoulder disorders in general practice: prognostic indicators of outcome. Br J Gen Pract. 1996; 46(410):519-523.

4. Kietrys DM, Palombaro KM, Azzaretto E, Hubler R, Schaller B, Schlussel JM, et al. Effectiveness of dry needling for upperquarter myofascial pain: a systematic review and meta-analysis. J Orthop Sport Phys. 2013; 43(9):620-634. https://doi.org/10.2519/ jospt.2013.4668

5. Pope DP, Croft PR, Pritchard CM, Silman AJ. Prevalence of shoulder pain in the community: the influence of case definition. Ann Rheum Dis. 1997; 56(5):308-312. https://doi.org/10.1136/ard.56.5.308

6. Parr JJ, Borsa PA, Fillingim RB, Tillman MD, Manini TM, Gregory CM, et al. Pain-related fear and catastrophizing predict pain intensity and disability independently using an induced muscle injury model. J Pain. 2012; 13(4):370-378. https://doi.org/10.1016/j. jpain.2011.12.011

7. Lentz TA, Barabas JA, Day T, Bishop MD, George SZ. The relationship of pain intensity, physical impairment, and pain-related fear to function in patients with shoulder pathology. J Orthop Sports Phys Ther. 2009; 39(4):270-277. https://doi.org/10.2519/jospt.2009.2879

8. Lethem J, Slade PD, Troup JD, Bentley G. Outline of a Fear-Avoidance Model of exaggerated pain perception--I. Behav Res Ther. 1983; 21(4):401-408. https://doi.org/10.1016/0005-7967(83)90009-8

9. Vlaeyen JWS, Linton SJ. Fear-avoidance and its consequences in chronic musculoskeletal pain: a state of the art. Pain. 2000; 85(3):317332. https://doi.org/10.1016/S0304-3959(99)00242-0

10. Vlaeyen JWS, Crombez G. Fear of movement / (re)injury, avoidance and pain disability in chronic low back pain patients. Manual Ther. 1999; 4(4):185-195. https://doi.org/10.1054/math.1999.0199

11. Swinkels-Meewisse IEJ, Roelofs J, Oostendorp RAB, VerbeekAL, Vlaeyen JW. Acute low back pain: pain-related fear pain catastrophizing influence physical performance perceived disability. Pain. 2006; 120(1-2):36-43.https://doi.org/10.1016/j.pain.2005.10.005

12. Scopaz KA, Piva SR, Wisniewski S, Fitzgerald GK. Relationships of fear, anxiety, and depression with physical function in patients with knee osteoarthritis. Arch Phys Med Rehabil. 2009; 90(11):1866-1873. https://doi.org/10.1016/j.apmr.2009.06.012

13. George SZ, Fritz JM, Erhard RE. A comparison of fear avoidance beliefs in patients with lumbar spine pain and cervical spine pain. Spine. 2001; 26(19):2139-2145. https://doi.org/10.1097/00007632-200110010-00019

14. Fritz JM, George SZ, Delitto A. The role of fear-avoidance beliefs in acute low back pain: relationships with current and future disability and work status. Pain. 2001; 94(1):7-15. https://doi.org/10.1016/S0304-3959(01)00333-5

15. Sabari JS, Maltzev I, Lubarsky D, Liszkay E, Homel P. Goniometric assessment of shoulder range of motion: comparison of testing in supine and sitting positions. Arch Phys Med Rehabil. 1998; 79(6):647-651. https://doi.org/10.1016/S0003-9993(98)90038-7

16. Palmer ML, Epler ME. Fundamentals of musculoskeletal assessment techniques. 2nd ed. Philadelphia: Lippincott Raven Publishers; 1998.

17. Hayes K, Walton JR, Szomor ZL, Murrell GA. Reliability of five methods for assessing shoulder range of motion. Aust J Physiother. 2001; 47(4):289-294. https://doi.org/10.1016/S0004-9514(14)60274-9

18. Tunca Yılmaz Ö, Yakut Y, Uygur F, Uluğ N. Turkish version of the Tampa Scale for Kinesiophobia and its test-retest reliability. Türk Fizyoterapi ve Rehabilitasyon Dergisi. 2011; 22:44-49 (in Turkish with abstract in English).

19. MacDermid JC, Solomon P, Prkachin K. The Shoulder Pain and Disability Index demonstrates factor, construct and longitudinal validity. BMC Musculoskelet Disord. 2006; 7:12. https://doi.org/10.1186/1471-2474-7-12

20. Beck AT, Epstein N, Brown G, Steer RA. An inventory for measuring clinical anxiety: psychometric properties. J Consult Clin Psychol. 1988; 56(6):893-897. https://doi.org/10.1037/0022-006X.56.6.893

21. Jason M. Beneciuk, Michael E. Robinson, Steven Z. George. Low Back Pain Subgroups using Fear-Avoidance Model Measures: Results of a Cluster Analysis. The Clinical Journal of Pain. 2012; 28(8):658-666. https://doi.org/10.1097/AJP.0b013e31824306ed

22. Feleus A, van Dalen T, Bierma-Zeinstra SM, Bernsen RM, Verhaar JA, Koes BW, et al. Kinesiophobia in patients with non-traumatic arm, neck and shoulder complaints: a prospective cohort study in general practice. BMC Musculoskelet Disord. 2007; 8:117. https:// doi.org/10.1186/1471-2474-8-117

23. Veeger HE, van der Helm FC. Shoulder function: the perfect compromise between mobility and stability. Journal of Biomechanics. 2007; 40(10):2119-2129. https://doi.org/10.1016/j.jbiomech.2006.10.016

24. Güney-Deniz H, Irem Kınıklı G, Çağlar Ö, Atilla B, Yüksel İ. Does kinesiophobia affect the early functional outcomes following total knee arthroplasty? Physiotherapy Theory and Practice. 2017; 33(6):448-453. https://doi.org/10.1080/09593985.2017.1318988

25. Brown ML, Plate JF, Von Thaer S, Fino NF, Smith BP, Seyler TM, et al. Decreased Range of Motion After Total Knee Arthroplasty Is Predicted by the Tampa Scale of Kinesiophobia. J Arthroplasty. 2016; 31(4):793-797. https://doi.org/10.1016/j.arth.2015.10.037

26. Bot SD, van der Waal JM, Terwee CB, van der Windt DA, Scholten RJ, Bouter LM, et al. Predictors of outcome in neck and shoulder symptoms: a cohort study in general practice. Spine (Phila Pa 1976). 2005; 30(16):E459-470. https://doi.org/10.1097/01. brs.0000174279.44855.02

27. Perrot S, Trouvin AP, Rondeau V, Chartier I, Arnaud R, Milon JY, et al. Kinesiophobia and physical therapy-related pain in musculoskeletal pain: A national multicenter cohort study on patients and their general physicians. Joint Bone Spine. 2018; 85(1):101-107. https://doi. org/10.1016/j.jbspin.2016.12.014

28. Damsgard E, Thrane G, Anke A, Fors T, Røe C. Activity-related pain in patients withchronic musculoskeletal disorders. Disabil Rehabil. 2010; 32(17):1428-1437. https://doi.org/10.3109/09638280903567877

29. Hanratty CE, Kerr DP, Wilson IM, McCracken M, Sim J, Basford JR, et al. Physical Therapists' Perceptions and Use of Exercise in the Management of Subacromial Shoulder Impingement Syndrome: Focus Group Study. Physical Therapy. 2016; 96(9):1354-1363. https://doi.org/10.2522/ptj.20150427 
30. Meeus M, Hermans L, Ickmans K, Struyf F, Van Cauwenbergh D, Bronckaerts L, et al. Endogenous pain modulation in response to exercise in patients with rheumatoid arthritis, patients with chronic fatiguesyndrome and comorbid fibromyalgia, and healthy controls: a double-blind randomized controlled trial. Pain Pract. 2015; 15(2):98-106. https://doi.org/10.1111/papr.12181

31. Koltyn KF, Brellenthin AG, Cook DB, Sehgal N, Hillard C. Mechanisms of exercise-induced hypoalgesia. J Pain. 2014; $15: 1294-1304$. https://doi.org/10.1016/j.jpain.2014.09.006

32. Buer N, Linton SJ. Fear-avoidance beliefs and catastrophizing:occurrence and risk factor in back pain and ADL in the general population. Pain. 2002; 99(3):485-491. https://doi.org/10.1016/S0304-3959(02)00265-8

33. Morris LD, Grimmer-Somers KA, Spottiswoode B, Louw QA. Virtual reality exposure therapy as treatment for pain catastrophizing in fibromyalgia patients: proof-of-concept study (Study Protocol). BMC Musculoskeletal Disorders. 2011; 12(1):85. https://doi. org/10.1186/1471-2474-12-85

34. Yilmaz Yelvar GD, Çırak Y, Dalkılınç M, Parlak Demir Y, Guner Z, Boydak A. Is physiotherapy integrated virtual walking effective on pain, function, and kinesiophobia in patients with non-specific low-back pain? Randomised controlled trial. Eurepan Spine Journal. 2017; 26(2):538-545. https://doi.org/10.1007/s00586-016-4892-7

How to cite this article: Burhan Fatih Kocyigit, Ahmet Akyol. The relationship between kinesiophobia and disability, pain and anxiety in patients with chronic shoulder pain: A case control study. J Clin Med Kaz. 2020; 3(57):29-34 